\title{
The 1965 Immigration Act: A Little Humility, Please!
}

\author{
Jason Richwine
}

When Congress passed the Immigration and Nationality Act of 1965, the bill's supporters seemed sure of one thing-its effects on the country's population would be minimal. "The bill will not flood our cities with immigrants. It will not upset the ethnic mix of our society,” Sen. Ted Kennedy stated succinctly. His brother, Attorney General Robert Kennedy, made the same prediction: "[The bill] would increase the amount of authorized immigration by only a fraction."

The Attorney General further claimed that only 5,000 immigrants from Asia would enter in the first year, and afterward "immigration from that source would virtually disappear.” Sen. Hiram Fong also insisted that Asian Americans “will never reach 1 percent of the population." Citing the greater emphasis on family reunification, the Washington Post editorialized that the bill "insured that the new immigration pattern would not stray radically from the old one."

The supporters were, of course, wrong. The number and diversity of immigrants increased more than they predicted over the short term, and far more than they predicted over the long term. Half a century later, their failed predictions still have lingering effects. Mass immigration is an ongoing lesson in how politicians, journalists, and "experts" of all stripes can be so consequentially wrong about the future.

To understand why the prognosticators erred, it is first important to knock down a caricature sometimes heard among modern critics-namely, that the 1965 Act simply threw open the doors to the Third World. It did not. The new policy laid the foundation for mass immigration, but future political developments were needed to fully exploit it.

1 The preceding quotes were collected by the Center for Immigration Studies, "The Legacy of the 1965 Immigration Act," September 1, 1995.

Jason Richwine is a public policy analyst in Washington, D.C. and a contributor to National Review; jason. richwine@gmail.com. He last appeared in these pages with his article "Low-Skilled Immigration and the Balkanized Campus," (Fall, 2018). 
Prior to 1965 , the U.S. allocated many immigration visas according to a national-origins formula that was first developed in 1921. The purpose of the formula was to ensure that the ethnic mix of immigrants stayed roughly in line with the ethnic mix of the American population. Although there had been several modifications to the formula leading up to 1965, Western Europe still received proportionately more visas than other parts of the world. The primary purpose of the 1965 Act was to equalize the visa allocations across countries, effectively ending national-origin preferences.

This reform was thought to be mostly symbolic, for two reasons. First, the act prioritized family reunification, meaning that most new immigrants would be co-ethnic with Americans who were already here. Spouses and minor children of U.S. citizens would continue to be unrestricted, and the "preference" categories subject to visa caps would be reserved mainly for other types of family admissions, such as adult siblings.

Second, the annual visa cap for the Eastern hemisphere would be raised by only 20,000 , for a total of 170,000 "preference" visas. That hardly seemed to qualify as opening the floodgates. The 1965 Act did create a separate quota for the Western Hemisphere of 120,000 visas, but these were not necessarily additional admissions, as there had been no official limitation on Western Hemisphere immigration prior to that time.

Accepting for a moment this narrow, short-term view of the 1965 Act, it is not hard to understand why contemporary critics were seen as objectively wrong. One such critic was Congressman William Miller, running mate to Republican presidential candidate Barry Goldwater. Two months before enduring a landslide defeat in the 1964 election, he had a warning for his Indiana audience. "In legislation which [President] Lyndon Johnson has designated as top priority, he now proposes that we completely abolish our selective system of immigration and instead open the floodgates for virtually any and all who would wish to come and find work in this country," he said. ${ }^{2}$

In modern terms, Miller's comments might be greeted with "Four Pinocchios" from the Washington Post and "Pants on Fire!" from Politifact. Twitter would consider appending a warning to any tweets that quoted him. The New York Times might declare in a headline that he made these claims

2 Quoted in the New York Times, "Miller Attacks Tariff Program: Says Johnson Would Flood U.S. With Foreign Goods," September 8, 1964. 
“without evidence.” After all, the bill clearly does not open any floodgates, nor does it allow just anyone to enter.

Sen. Spessard Holland of Florida was another skeptic. He objected to allowing immigration from all parts of the world rather than favoring the ancestral homelands of current Americans. “This is a complete and radical departure from what has always heretofore been regarded as sound principles of immigration," the senator told his colleagues. ${ }^{3}$ Put in modern terms once again, the media might accuse Sen. Holland of spreading a conspiracy theory favored by white supremacists. After all, the logic of family reunification seemed clear-no major changes to the ethnic composition.

The great error made by proponents of the 1965 Act was not in misstating or ignoring provisions of the legislation; rather, it was in failing to anticipate how those provisions would interact with future migration pressures. At least some proponents seemed not to anticipate any migration pressure at all. "It is obvious ... that the great days of immigration have long since run their course," Congressman Sidney Yates told his colleagues. Similarly, Secretary of State Dean Rusk testified that "I don't think we have a particular picture of a world situation where everybody is just straining to move to the United States."

In fact, millions were straining to move to the U.S., and the evidence for that quickly mounted. The number of new permanent residents per year jumped from about 300,000 in 1965 to 400,000 in 19735-not an open floodgate, but certainly more than the drop in the bucket that the act's supporters predicted.

Over the longer term, removing the restrictions based on national origin helped provide legal immigrants with a sufficient toehold. Then the law's family preferences enlarged their numbers, resulting in a feedback effect. When Congress expanded certain types of immigrant visas-for example, refugee resettlement in the 1970s and 1980s, and skilled workers in the 1990s-it created new self-expanding clusters. Illegal immigration worked much the same way. Once members of those families gained legal status-either through birthright citizenship or an amnesty - they could take advantage of the family preferences.

As immigration from different parts of the world increased, new political movements developed to protect the flow. Restricting certain preference categories, for example, has been politically impossible because it offends ethnic

CIS, "The Legacy of the 1965 Immigration Act."

4 Ibid.

5 Migration Policy Institute, "Legal Immigration to the United States, 1820-Present," accessed October 2020 . 
constituencies who most benefit from them. Indeed, when President Trump proposed limiting family-based green cards to spouses and minor children, House Speaker Nancy Pelosi called it "part of the Trump Administration's unmistakable campaign to make America white again.”

The solution to ethnic squabbles over visas has often been to simply expand immigration even further. For example, the family-preference system championed by the Irish-American Ted Kennedy ironically became a barrier to Irish nationals who wished to come to the U.S. In response, the senator pushed for a "diversity immigrant lottery" that allocated visas to countries that were not otherwise receiving many. Irrational as it may seem to hand out visas on a literally random basis, with recipients needing only minimal qualifications, ethnic politics have kept this program alive for thirty years and counting.

Where has all of this left us? For the fiftieth anniversary of the 1965 Act, the Pew Research Center examined how immigration has changed the demographics of the U.S. ${ }^{7}$ The country's total population in 2015 was 324 million, but without post-1965 immigration it would have been closer to 252 million-a difference of 72 million people. As for changes in ethnic composition, the U.S. is now 18 percent Hispanic and 6 percent Asian. Without post-1965 immigration, those numbers would be 8 percent and less than 1 percent, respectively.

Of course, immigration was not zero prior to the 1965 Act, and several subsequent laws passed by Congress contributed to the post-1965 flow. However, the act laid the foundation for mass immigration in a way that politicians were unable or unwilling to see. The act's contemporary critics were sometimes overheated, but their instincts proved to be sound-fundamental changes to immigration policy, though perhaps not so consequential in the short term, could have major long-term consequences.

The lessons for today are clear. All of the "fact checks" and "explainers" in the world cannot reduce complex systems such as international migration into a simple list of bite-sized truths. Instead of rushing to shout "Pants on fire!" at skeptics, experts should recognize that skepticism often derives from a simple recognition of uncertainty. A willingness to admit “we just don't know” could go a long way toward improving both political discourse and public policy in the future.

6 U.S. Representative Nancy Pelosi, Press release, January 25, 2018.

7 Pew Research Center, "Modern Immigration Wave Brings 59 Million to U.S., Driving Population Growth and Change Through 2065," September 28, 2015. 